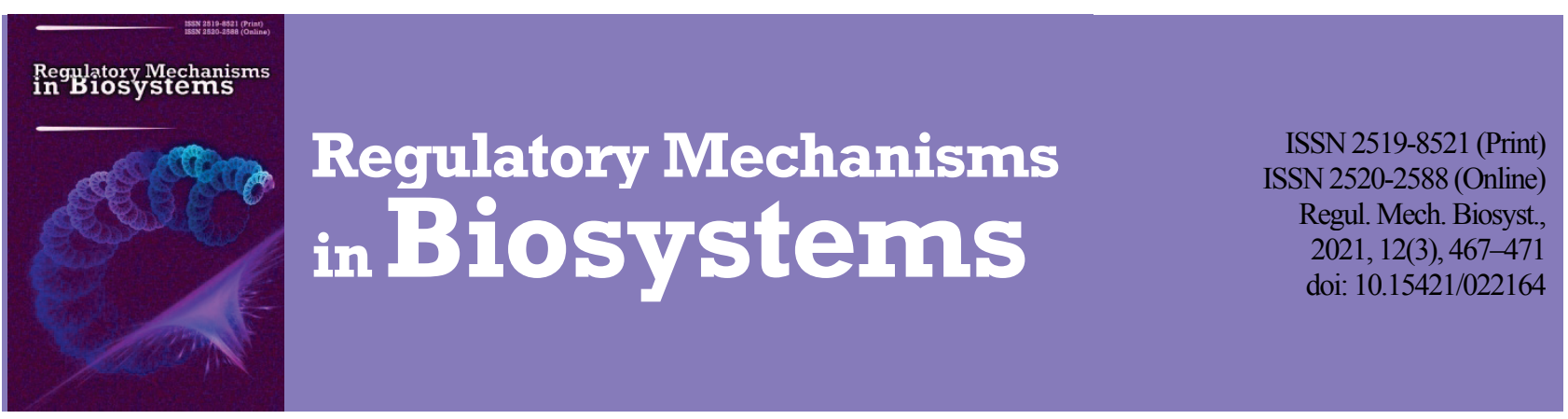

\title{
Effect of Heracleum sosnowskyi extract aqueous solution on the Allium cepa root meristem
}

\author{
M. V. Smirnova, V. A. Kotelnikov \\ Kola Science Center of the Russian Academy of Sciences, Apatity, Russia
}

Article info

Received 13.07.2021

Received in revised form 10.08.2021

Accepted 11.08.2021

Kola Science Center

of the Russian Academy

of Sciences, Fersman st., 14

Apatity, 184209, Russia.

Tел:+7-952-298-67-42.

E-mail:zbe3do4et@mail.ru

\begin{abstract}
Smirnova, M. V., \& Kotelnikov, V. A. (2021). Effect of Heracleum sosnowskyi extract aqueous solution on the Allium cepa root meristem. Regulatory Mechanisms in Biosystems, 12(3), 467-471. doi:10.15421/022164
\end{abstract}

Heracleum sosnowskyi (Apiaceae) contains a lot of useful chemical ingredients that can be used in industry, medicine and other fields as plant component extracts and as chemical compounds that have been extracted in different ways, which requires the last to be tested for chemical safety, including a genotoxic test in vivo. In the present paper, the 96-hour effect of the $H$. sosnowskyi extract aqueous solution at concentrations of $0.01,0.05,0.10$, and $0.50 \mathrm{~mL} / \mathrm{L}$ on the genetic apparatus and mitotic activity of the cells of the Allium cepa (Alliaceae) root meristem is discussed. Distilled water was applied as a negative control, and hydrogen peroxide $1 \%$ as a positive one. The extract was prepared from the plant's fresh leaves by soaking them in acetone. It was then distilled at $57^{\circ} \mathrm{C}$ and diluted with distilled water to obtain the experimental concentrations. As extract content in the aqueous solution increased, a statistically significant decrease in mitotic activity, an increase in aberrant cell percentage and a concentration-dependent inhibition of root growth were observed. In the $0.5 \mathrm{~mL} / \mathrm{L}$ solution, if compared against the other experimental concentrations, an increase in the metaphase, anaphase and telophase indices along with a decrease in the prophase index were observed. The most common aberrations for all the concentrations were lagging and sticking chromosomes, anaphase bridges, ring chromosomes and nuclear buds. The same solution and the positive control produced membrane damage; giant and ghost cells. The results of the experiment performed have demonstrated the extract's aneugenic effect that causes spindle disturbance, mitodepression and inhibits the cells of the Allium cepa root meristem, prevails over its clastogenic effect.

Keywords: genotoxicity; mitosis; plant extract; mitotic activity; lagging and sticking chromosomes; anaphase bridges; ring chromosomes; nuclear buds.

\section{Introduction}

In Russia and many other countries, Heracleum sosnowskyi has ceased to be a promising forage plant and turned into an invasive species (Tkachenko, 2015; Visockiene, 2020). Excreting allelopathic substances and spreading a huge number of seeds (Jakubska-Busse, 2013), the plant conquers new territories and present a clear danger for the biodiversity, economies and the people of the land. Its juice has photosensitizing action making it potentially hazardous for humans. Some data say the juice of other hogweed species cause mutations in mammal lymphocytes (Bogucka-Kocka et al., 2008) and is toxic for aquatic organisms even without photoactivation (Moshafi et al., 2009).

Although the hogweed that has failed to become a proper greening plant and livestock feed, is a great raw material available in large quantities. For instance, the aboveground part of $H$. sosnowskyi is currently tested as an additive for a construction material (Musorina et al., 2019) and can be used in cardboard production (Musikhin \& Sigaev, 2006). As for its chemical composition, the plant is rich in proteins, vitamins, furanocoumarins, ethers, etc. making it a proper raw material for manufacturing food additives and in this way reducing its harmfulness and rendering it potentially useful in medicine and science (Jahodová et al., 2007; Shakhmatov, 2016). The chemical compounds extracted from $H$. sosnowskyi are used as wound-healing, antiseptic (Walacek et al., 2015; Bahadori et al., 2016) and anti-inflammatory agents; they also have antioxidant (Souri, 2008; Firuzi et al., 2010) and cytotoxic effects (Gao et al., 2014; Maggi et al., 2014). Knowledge has been accumulated about the composition of the plant's ether oils, coumarin compounds, leaf organs (trichomes), etc. (O'Neill et al., 2013; Hosseinzadeh et al., 2019; Laman \& Usik, 2020). The furocoumarins (angelicin, methoxalen and imperatorin) extracted from H. sosnowskyi exert broad-spectrum biological effects (Trott et al., 2008).
However, application of the plant's compounds for medical and other purposes requires their toxicity and genotoxicity to be properly tested.

Using plants as test systems for defining the toxicity profile of chemical, biological and physical factors has become widely spread in recent years (Olorunfemi et al., 2011; Prajitha \& Thoppil, 2015; Madić et al., 2017) mainly due to the simplicity and affordability of the experiment. Testing on plants does not infringe ethical principles and provides a solid amount of data on the potential harm done to DNA at the level of whole organism unlike cell cultures (Nabeel et al., 2008; Li et al., 2015).

The plant most commonly used for cytological and genotoxic monitoring has long been Allium cepa due to the ease of working with the cells of its root meristem that are large (both cells and chromosomes) and of small quantity $(2 n=16)$. The Allium assay has been the standard sensitivity test in vivo and its results can be used to assess genotoxicity for other living forms, including humans (Fiskesjo, 1985; Tedesco \& Laughinghouse, 2012; Bonciu et al., 2018). In the presented study, the Allium assay was used to estimate the geno-and cytotoxicity of the H. sosnowskyi extract aqueous solution.

\section{Materials and methods}

The leaves of $H$. sosnowskyi collected from a boggy roadside $\left(67.601986^{\circ} \mathrm{N} 33.416213^{\circ} \mathrm{E}\right)$ were soaked in acetone in proportion 1:1 ( $1 \mathrm{~kg}$ of leaves). The solution was distilled at $57^{\circ} \mathrm{C}$. The residue, a grained dark-green liquid, was diluted with distilled water to obtain an aqueous solution at concentrations of $0.01,0.05,0.10$, and $0.50 \mathrm{~mL} / \mathrm{L}$.

The bulbs Allium cepa of Stuttgarter Riesen $(2 \mathrm{n}=16)$ bought in a shop were kept in a dark, cold room for 14 days. From these, bulbs of similar diameter were selected and their dead-skin layer was removed. Following the test design by Fiskesjo (Wang et al., 1997), the selected 
bulbs were left to germinate in distilled water for 24 hours. After the germination period, 40 bulbs were selected ( 5 bulbs per concentration). As controls, bulbs with $2-3 \mathrm{~mm}$ roots were selected. Distilled water was applied as a negative control, and hydrogen peroxide $1 \%$ as a positive one (Akwu et al., 2019). The experiment lasted for 96 hours in a dark room at room temperature. All the exposure conditions and monitor data were encrypted. Upon completion, the roots were cut off, their length measured in millimeters to estimate their growth (Fiskesjo, 1985; Wierzbicka \& Antosiewicz, 1988; O'Hare et al., 1995). The roots were fixed in vinegar alcohol (96\% of ethanol + glacial acetic acid in proportion 3:1) for a day and then rinsed three times in $80 \%$ ethanol (one hour each time) to be placed in sealable test-tubes for long-time storing.

To prepare the specimen, the roots were hydrolyzed and stained in ceramic crucibles in boiling 2\% aceto-orcein stain solution (NPP PanEco, Russia). After cooling, the crucibles were left for $24-72$ hours at $4{ }^{\circ} \mathrm{C}$ for the roots to stain (Medvedeva et al., 2014).

For every mentioned concentration and control, 15 squash specimen samples were prepared from 15 roots. A root tip with growth zone of 3 $4 \mathrm{~mm}$ in length was cut off with a scalpel to be placed on a specimen glass in a drop of glacial acetic acid. Then it was covered by a cover glass, pressed with a napkin and accurately squashed by the tapping motions of the blunt tip of a glass rod. The edges of the cover glass were then sealed with nail polish to prevent the acetic acid evaporating and extend the observation time. For each specimen, about 1000 cells were counted with phase

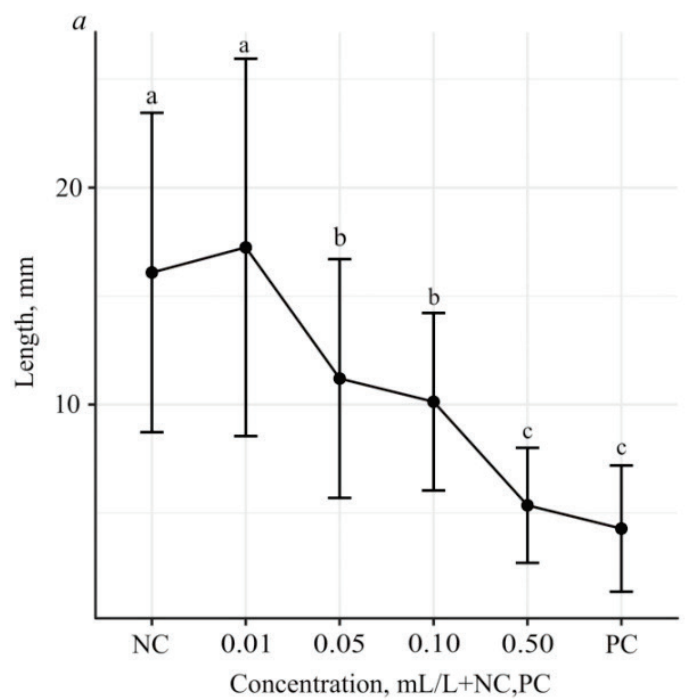

and chromosome aberration marked at $\times 400$ and $\times 1000$ (in immersion oil) magnification of a Micromed 1, v. 1-20 microscope (Micromed, Russia, 2019). The shooting was performed using a digital Toupcam 2.0 Cmos Camera (Touptec, China, 2019) equipped with the ToupView software for the 1/2.7" sensor of $1920 \times 1080$ pixel resolution. In total, more than 90000 cells were counted. The mitotic index (MI) was calculated as a percentage ratio of the number of all dividing cells to the general number of the cells calculated in a specimen. The proportions of mitotic phases were calculated in the same way.

Statistical analysis was carried out using the $\mathrm{R}$ programming language (free software environment for statistical computing, New Zealand). The sample distribution normality was determined following the Shapiro-Wilk test. The differences in MI; root length; between experiment and control groups were verified with a one-way ANOVA. The level of significance was accepted to be $\mathrm{P}<0.05$. Additionally, the Tukey multiple pair-wise comparisons were performed. The differences in phase indices were calculated using the Kruskal-Wallis statistic and Dunn's multiple comparison post hoc test.

\section{Results}

The $H$. sosnowskyi aqueous solution had an antiproliferative effect on the cells of the $A$. cepa root as can be seen from the results of graphical and statistical analysis of root lengths and mitotic index (Fig. 1).

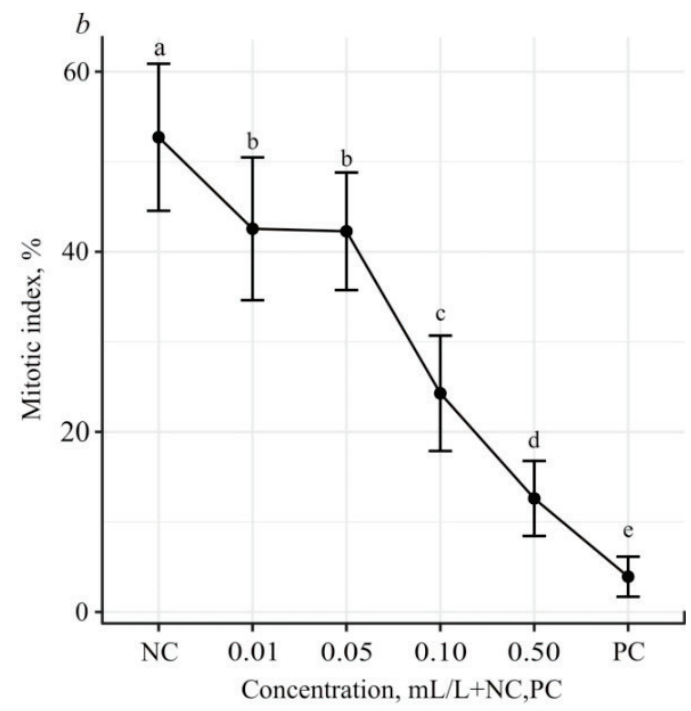

Fig. 1. Results of graphical and statistical analysis of root lengths and mitotic index of the $A$. cepa roots treated with the $H$. sosnowskyi aqueous solution: $a$-root length dependence graph, $\mathrm{mm}(\mathrm{x} \pm \mathrm{SD}, \mathrm{n}=174) ; b$-mitotic index dependence graph, $\%(\mathrm{x} \pm \mathrm{SD}, \mathrm{n}=15) ; \mathrm{NC}$-negative control (distilled water), $\mathrm{PC}$ - positive control $\left(\mathrm{H}_{2} \mathrm{O}_{2}, 1 \%\right)$, different letters $(a, b, c, d, e)$ were significantly different according to Tukey-test $\mathrm{P}<0.05$

The experiments revealed that the $H$. sosnowskyi aqueous solution inhibited root growth 96 hours after application, and this inhibition was concentration-dependent. While in pair $\mathrm{NC}-0.01 \mathrm{~mL} / \mathrm{L}$ a statistically insignificant growth stimulation was observed, in pairs $0.05-0.10$ and 0.50 $\mathrm{mL} / \mathrm{L}-\mathrm{PC}$ no statistical differences were noted.

The MI exhibited a reducing trend with concentration increase. In almost all the cases of pair-wise comparison, statistically significant differences $(P<0.05)$ were observed, and only in pair $0.01-0.05 \mathrm{~mL} / \mathrm{L}$ were no such differences registered. The most expressed effect on the number of dividing cells was observed for the $0.50 \mathrm{~mL} / \mathrm{L}$ concentration. In the same solution, a statistically significant reduction of prophase index and an increase of metaphase, anaphase and telophase indices were observed if compared to other experimental data (Table 1). Statistically significant differences of prophase index were also registered in PC, 0.01 and $0.10 \mathrm{~mL} / \mathrm{L}$ solutions. Cytogenetic analysis of the specimen revealed different kinds of aneugenic and clastogenic damage done (Table 2).

Table 2 demonstrates there is a positive correlation between concentration increase and proportion of aberrant cells as well as the prevalence of aneugenic effects over clastogenic ones, which is evidence of the low clastogenic activity of the solution at such concentration. If compared to the normal mitosis phases (Fig. 2) the most common anomalies caused by the $H$. sosnowskyi aqueous solutions included lagging and sticking chromosomes and nuclear buds (aneugenic effects, Fig. 3); anaphase bridges and ring chromosomes (clastogenic effects, Fig. 4).

\section{Table 1}

Mitotic and phase indices for the meristematic cells of the A. cepa roots treated with the $H$. sosnowskyi extract aqueous solution $(\mathrm{x} \pm \mathrm{SD}, \mathrm{n}=15)$

\begin{tabular}{lccccc}
\hline $\begin{array}{c}\text { Concentration, } \\
\mathrm{mL} / \mathrm{L}\end{array}$ & $\begin{array}{c}\text { Mitotic } \\
\text { index, \% }\end{array}$ & $\begin{array}{c}\text { Prophases, } \\
\%\end{array}$ & $\begin{array}{c}\text { Metaphases, } \\
\%\end{array}$ & $\begin{array}{c}\text { Anaphases, } \\
\%\end{array}$ & $\begin{array}{c}\text { Telophases, } \\
\%\end{array}$ \\
\hline $\begin{array}{l}\mathrm{NC}, \mathrm{H}_{2} \mathrm{O} \\
\text { distilled }\end{array}$ & $52.7 \pm 8.2^{\mathrm{a}}$ & $82.3 \pm 6.4^{\mathrm{a}}$ & $8.3 \pm 2.8^{\mathrm{a}}$ & $3.2 \pm 1.2^{\mathrm{a}}$ & $6.2 \pm 3.5^{\mathrm{a}}$ \\
0.01 & $42.6 \pm 7.9^{\mathrm{b}}$ & $76.7 \pm 9.8^{\mathrm{a}}$ & $12.1 \pm 5.4^{\mathrm{a}}$ & $3.6 \pm 2.1^{\mathrm{a}}$ & $7.5 \pm 3.0^{\mathrm{a}}$ \\
0.05 & $42.3 \pm 6.5^{\mathrm{b}}$ & $82.5 \pm 3.7^{\mathrm{a}}$ & $7.6 \pm 2.5^{\mathrm{a}}$ & $5.0 \pm 2.0^{\mathrm{a}}$ & $4.9 \pm 1.7^{\mathrm{a}}$ \\
0.10 & $24.3 \pm 6.4^{\mathrm{c}}$ & $75.5 \pm 12.9^{\mathrm{a}}$ & $11.6 \pm 6.8^{\mathrm{a}}$ & $5.2 \pm 3.0^{\mathrm{a}}$ & $7.8 \pm 4.2^{\mathrm{a}}$ \\
0.50 & $12.6 \pm 4.2^{\mathrm{d}}$ & $23.1 \pm 11.5^{\mathrm{b}}$ & $33.9 \pm 9.4^{\mathrm{b}}$ & $21.2 \pm 8.6^{\mathrm{b}}$ & $21.9 \pm 7.1^{\mathrm{b}}$ \\
$\mathrm{PC}, 1 \% \mathrm{H}_{2} \mathrm{O}_{2}$ & $3.9 \pm 2.2^{\mathrm{e}}$ & $88.1 \pm 25.7^{\mathrm{c}}$ & $5.9 \pm 15.9^{\mathrm{c}}$ & $4.7 \pm 9.9^{\mathrm{c}}$ & $1.3 \pm 2.0^{\mathrm{c}}$ \\
\hline
\end{tabular}

Note: different letters indicate values that differ significantly from each other in the same columns of the table by comparison with the Dunn's test, $\mathrm{P}<0.05$.

The maximum number of sticking chromosomes were registered for the $0.5 \mathrm{~mL} / \mathrm{L}$ solution, but this effect was not concentration-dependent. The solution also contained a large number of nuclear buds. 
Table 2

Aberrations in the dividing cells of the $A$. cepa roots treated the $H$. sosnowskyi extract aqueous solution

\begin{tabular}{lccccc}
\hline $\begin{array}{c}\text { Concentration, } \\
\mathrm{mL} / \mathrm{L}\end{array}$ & $\begin{array}{c}\text { Chromo- } \\
\text { some lag- } \\
\text { ging, cells }\end{array}$ & $\begin{array}{c}\text { Chromo- } \\
\text { some stick- } \\
\text { iness, cells }\end{array}$ & $\begin{array}{c}\text { Anaphase } \\
\text { bridges, } \\
\text { cells }\end{array}$ & $\begin{array}{c}\text { Ring chro- } \\
\text { mosomes, } \\
\text { cells }\end{array}$ & $\begin{array}{c}\text { Aberrant } \\
\text { mitotic } \\
\text { cells*, \% }\end{array}$ \\
\hline $\mathrm{NC}, \mathrm{H}_{2} \mathrm{O}$ & 8 & 0 & 3 & 0 & 0.2 \\
distilled & 1 & 36 & 0 & 0 & 6.3 \\
$\mathrm{PC}, \mathrm{H}_{2} \mathrm{O}_{2}, 1 \%$ & 1 & 88 & 10 & 0 & 9.9 \\
0.50 & 89 & 53 & 5 & 0 & 4.5 \\
0.10 & 107 & 58 & 9 & 0 & 1.8 \\
0.05 & 50 & 47 & 0 & 8 & 1.3 \\
0.01 & 22 & & & & \\
\hline
\end{tabular}

Note: the calculations were made in relation to the number of dividing cells.

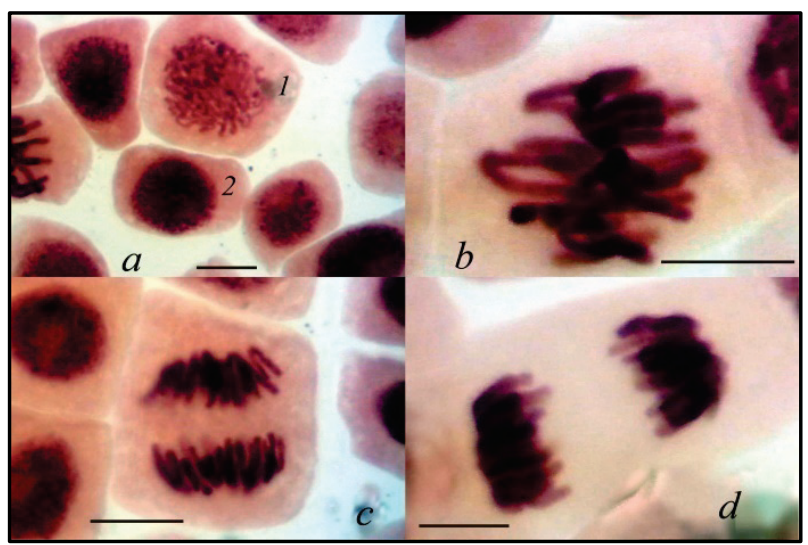

Fig. 2. Mitosis phases in the meristematic cells of the $A$. cepa roots treated with NC (distilled water): $\mathrm{a}_{1}$ - prophase, $\mathrm{a}_{2}-$ interphase, $b$-metaphase, $c$-anaphase, $d$-telophase; scale bars $-10 \mu \mathrm{m}$

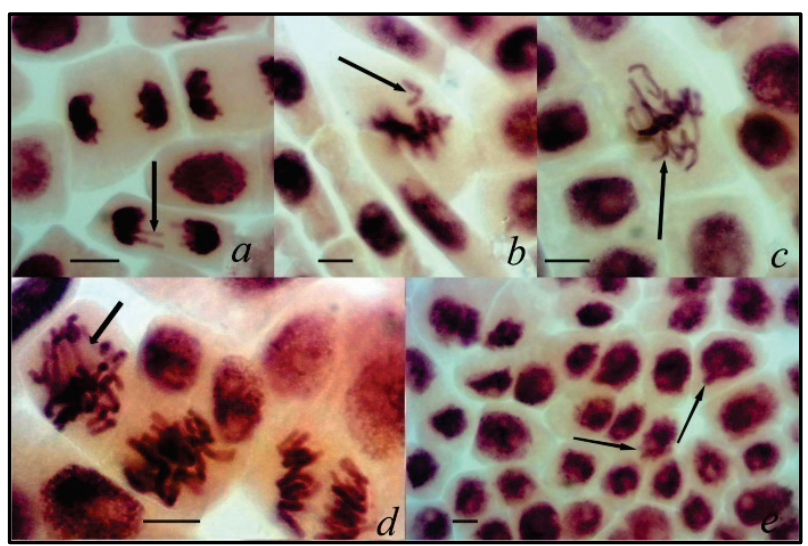

Fig. 3. Aneugenic effects in the meristematic cells of the $A$. cepa roots treated with the $H$. sosnowskyi extract aqueous solution: $a$-chromosome lagging in telophase; $b, c$-chromosome lagging in metaphase; $d$-chro-

mosome sticking in anaphase; $e$-nuclear buds; scale bars $-10 \mu \mathrm{m}$

The following aberrations formed a separated group: giant cells; enucleate (ghost) cells and cells with defective interphase membranes (Table 3). These anomalies occurred either in the solution with the highest extract concentration or in $\mathrm{H}_{2} \mathrm{O}_{2}, 1 \%$ (Fig. 5).

\section{Discussion}

H. sosnowskyi is currently considered as a source of biologically active compounds such as furocoumarins, e.g. its leaves contain angelicin, bergapten, methoxsalen and umbelliferon. Bergapten and methoxsalen are used to treat certain skin diseases, and umbelliferon has anticoagulation properties and is applied for thrombosis treatment (Georgievsky et al., 1990). In our study hogweed extract aqueous solution was investigated, which, as the aqueous solutions of other plant extracts, is a complex mixture of chemical compounds that have their effect on the processes occurring in a living organism. These effects can be synergetic, antagonistic or additive and determine the changes of genetic material. To register and estimate these changes different test systems are applied, higher plants among them.

Table 3

Aberrations in the meristematic cells of the $A$. cepa roots

treated with the $H$. sosnowskyi extract aqueous solution $(\mathrm{N}=15000)$

\begin{tabular}{lcccc}
\hline $\begin{array}{c}\text { Concentration, } \\
\mathrm{mL} / \mathrm{L}\end{array}$ & $\begin{array}{c}\text { Nuclear } \\
\text { buds, cells }\end{array}$ & $\begin{array}{c}\text { Ghost and } \\
\text { giant cells }\end{array}$ & $\begin{array}{c}\text { Cells with defective } \\
\text { membranes }\end{array}$ & $\begin{array}{c}\text { Aberrant } \\
\text { cells*, } \%\end{array}$ \\
\hline $\mathrm{PC}, \mathrm{H}_{2} \mathrm{O}_{2}, 1 \%$ & 0 & 89 & 125 & 1.4 \\
0.5 & 182 & 76 & 86 & 2.3 \\
\hline
\end{tabular}

Note: the calculations were made in relation to the total cell count.

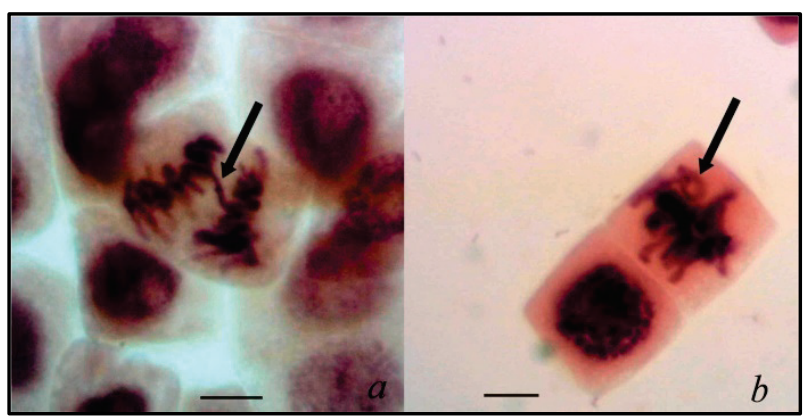

Fig. 4. Clastogenic effects in the meristematic cells of the $A$. cepa roots treated with the $H$. sosnowskyi extract aqueous solution: $a$ - anaphase bridge; $b$-ring chromosome; scale bars $-10 \mu \mathrm{m}$

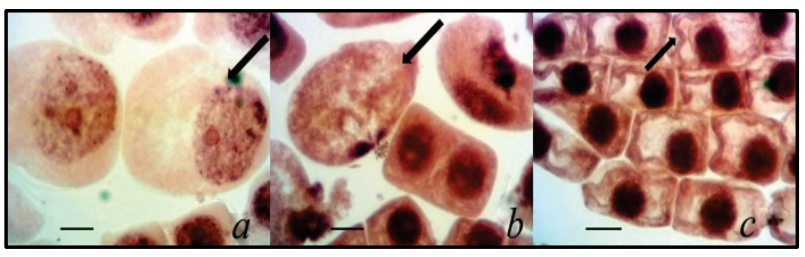

Fig. 5. Aberrations in the meristematic cells of the $A$. cepa roots treated with the $H$. sosnowskyi extract aqueous solution: $a$ - giant cells; $b$ - ghost cell; $c$-cells with defective membranes; scale bars $-10 \mu \mathrm{m}$

For the time being, apart from A. cepa, the root meristem of many other higher plants such as barley (Hordeum vulgare L.), beans (Vicia faba L.) and corn (Zea mays L.) are used to study both toxic and genotoxic factors of different nature (Grant, 1994). However, due to the high proportion of mitosis cells, its high sensitivity and easiness (Leme \& MarinMorales, 2009), A. cepa has taken a clear lead as an experimental object, to the degree that Grant (1982) even suggested making the Allium assay the standard test for chromosome damage assessment. This test includes several parameters for proper estimation of cyto- and genotoxicity patterns such as root lengths (growth index); mitotic index; cell percentage in each mitosis phase; aneugenic and clastogenic effects.

Mitotic index reduction in the meristematic cells of $A$. cepa roots is related to the mitodepressive effect of tested substances (Akinboro \& Bakare, 2007; Sharma \& Vig, 2012). The ability of plant extract aqueous solution to inhibit cell proliferation, analogous to the one considered in this investigation, has been described earlier in studies of both potential and well-known medicinal and industrial plants (De Abreu et al., 2019; Madike et al., 2019). The discussed effect is caused either by DNA synthesis inhibition in the S-phase (El-Ghamery et al., 2000) or by cell-cycle blocking in the $\mathrm{G}_{2}$-phase that leads to mitosis inhibition in a cell (Christopher \& Kapoor, 1988; Sudhakar et al., 2011).

The prophase index reduction is related to both the antiproliferation effect with cell-cycle blocking in the $\mathrm{G}_{2}$-phase and a faster passing of the prophase stage when the spindle apparatus is disrupted and pathological mitosis occurs (Karpova at al., 2020). The aberrations detain a cell in the metaphase, anaphase and telophase phases and lead to the increase of the mentioned indices. A similar indices shift has been observed in an earlier study of higher hogweed extract concentrations (Pesnya et al., 2017).

The mitosis changes and chromosome anomalies accounted for during the Allium assay are divided into two groups, known in the literature 
as aneugenic (lagging and sticking chromosomes, and nuclear buds) and clastogenic (ring chromosomes and anaphase bridges) (Sharma et al., 1990; Bonciu, 2018). These changes are related to DNA rupture, chromosome decay, mitotic spindle disturbance and cytokinesis inhibition. Chromosome lagging occurs due to the division spindle disturbance caused by inhibition of cytoskeletal proteins and tubulin polymerization (Timoshevsky \& Nazarenko, 2006; Bonciu et al., 2018). Chromosome sticking, on the other hand, is a reaction to compound toxicity and often results in cell death. There are several degrees of chromosome sticking in anaphase and telophase (light, moderate and severe). In its classical understanding, the term refers to the severe degree when the chromosomes form an amorphic mass (cluster) due to the functional defect of the specific non-histone proteins organizing chromosomes in mitosis for chromatid segregation and division (Gaulden, 1987; Ribeiro, 2018). Nuclear buds, on the other hand, occur when chemical compounds affect a cell's mitotic cycle and is related to the processing following chromosome lagging when the last are engaged by the nuclear membrane earlier than by the pole chromosomes (Serrano-Garcia \& Monteiro-Montoya, 2001). Some authors insist the buds occur due to polyploidization and amplification of the genetic material that is removed from the nucleus but remains bound to the nuclear membrane (Fernandes et al., 2007; Fenech et al., 2011). Chromosome and chromatid sticking lead to clastogenic effects, in particular anaphase and telophase bridges. Such bridges can be the product of unbalanced chromosome segment translocation or inversion (Kuras, 2004; Gomurgen, 2005). As for the ring chromosomes, they form after ruptures in both arms of a single chromosome and coupling of the non-centromeric fragments (Bonciu et al., 2018).

In our study, giant and enucleate (ghost) cells with damaged membranes were observed in the root cap and root division zones. The giant cells form when the cells have entered mitosis but not yet finished the cytoplasmic division (Kenne et al., 1986). The ghost cells, on the other hand, are dead cells in which the nucleus and cytoplasmic structures cannot be stained (Ribeiro, 2018). The membranes are damaged due to the effect of the membrane enzymes produced by lipid peroxidation or due to reducing cellulose content (Sultan \& Celik, 2007, 2010).

\section{Conclusion}

Our study has demonstrated that all the concentrations of the H. sosnowskyi extract aqueous solution prepared from fresh leaves had mitodepressive effect on the meristematic cells of the $A$. cepa roots, which manifested itself in statistically significant and concentration-dependent reduction of root length and MI. In the $0.5 \mathrm{~mL} / \mathrm{L}$ solution, the phase indices were modified in such a way that the proportion of prophases was reduced and that of metaphases, anaphases and telophases increased. A positive correlation has been discovered between the extract concentration and the number of aberrant cells in mitosis. The aqueous solution's effect was mainly aneugenic and manifested itself in lagging and sticking chromosomes, and nuclear buds. As for clastogenic aberrations, they included anaphase bridges and ring chromosomes. Other changes included ghost and giant cells, and cells with disrupted membranes.

The work was done within the framework of the topic of the search for new natural sources of adaptogenic compounds of research work No. 0186-2019-0009, approved for 2019-2021 by the Ministry of Science and Higher Education of the Russian Federation at the "Kola Scientific Center of the Russian Academy of Sciences" (KSC RAS).

The authors declare no conflict of interest.

\section{References}

Akinboro, A., \& Bakare, A. A. (2007). Cytotoxic and genotoxic effects of aqueous extracts of five medicinal plants on Allium cepa L. Journal Ethnopharmacology, $112(3), 470-475$.

Akwu, N. A., Naidoo, Y., \& Singh, M. (2019). Cytogenotoxic and biological evaluation of the aqueous extracts of Grewia lasiocarpa: An Allium cepa assay. South African Journal of Botany, 125, 371-380.

Bahadori, M. B., Dinparast, L., \& Zengin, G. (2016). The genus Heracleum: A comprehensive review on its phytochemistry, pharmacology, and ethnobotanical values as a useful herb. Comprehensive Reviews in Food Science and Food Safety, 15(6), 1018-1039.

Bogucka-Kocka, A., Smolarz, H., \& Kocki, J. (2008). Apoptotic activities of ethanol extracts from some Apiaceae on human leukemia cell lines. Fitoterapia, 79, 487-497.

Bonciu, E., Firbas, P., Fontanetti, C. S., Wusheng, J., Karaismailoğlu, M. C., Liu, D., Menicucci, F., Pesnya, D. S., Popescu, A., Romanovsky, A. V., Schiff, S., Ślusarczyk, J., De Souza, C. P., Srivastava, A., Sultan, A. O., \& Papini, A. (2018). An evaluation for the standardization of the Allium cepa test as cytotoxicity and genotoxicity assay. Caryologia, 71(3), 191-209.

Christopher, H. B., \& Kapoor, M. B. (1988). The cytogenetic effects of sodium Salicylate on the root meristem cells of Allium sativa L. Cytologia, 54, 203-209.

Cock, M. J. W., Eckstein, L., Evans, H. C., \& Fröberg, L. (2007). Ecology and management of giant hogweed (Heracleum mantegazzianum). CABI, Institute of Botany, Academy of Sciences of the Czech Republic, город?.

De Abreu, J. C., De Santana, R. A., Ribeiro, G. R. H., Dantas, M. M., Guisso, L. F., Valente, L. L., Luiz Silva, W. S., Silva, D. R., Barbieri, R. S., \& Da Costa, N. M. A. (2019). Effects cytotoxic and genotoxic of aqueous extract of fennel (Foeniculum vulgare var. vulgare Mill.). International Journal of Advanced Engineering Research and Science, 6(3), 230-236.

El-Ghamery, A. A., El-Nahas, A. I., \& Mansour, M. M. (2000). The action of atrazine herbicide as an inhibitor of cell division on chromosomes and nucleic acids content in root meristems of Allium cepa L. and Vicia faba L. Cytologia, 65(3), 277-287.

Fenech, M., Kirsch-Volders, M., Natarajan, A. T., Surralles, J., Crott, J. W., Parry, J., Norppa, H., Eastmond, D. A., Tucker, J. D., \& Thomas, P. (2011). Molecular mechanisms of micronucleus, nucleoplasmic bridge and nuclear bud formation in mammalian and human cells. Mutagenesis, 26(1), 125-132.

Fernandes, T. C. C., Mazzeo, D. E. C., \& Marin-Morales, M. A. (2007). Mechanism of micronuclei formation in polyploidizated cells of Allium cepa exposed to trifluralin herbicide. Pesticide Biochemistry and Physiology, 88(3), 252-259.

Firuzi, O., Asadollahi, M., Gholami, M., \& Javidnia, K. (2010). Composition and biological activities of essential oils from four Heracleum species. Food Chemistry, 122, 117-122.

Fiskesjö, G. (1985). The Allium-test as a standart in environmental monitoring. Hereditas, 102(1), 99-112.

Gao, Y., Liu, Y., Wang, Z., \& Zhang, H. (2014). Chemical constituents of Heracleum dissectum and their cytotoxic activity. Phytochemistry Letters, 10, 276-280.

Gaulden, M. E. (1987). Hypothesis: Some mutagens directly alter specific chromosomal proteins (DNA topoisomerase 11 and peripheral proteins) to produce chromosome stickiness, which causes chromosome aberrations. Mutagenesis, 2, 357-365.

Georgievskij, V. P., Komissarenko, N. F., \& Dmitruk, S. E. (1990). Biologicheski aktivnye veshhestva lekarstvennykh rastenij [Biologically active substances of medicinal plants]. Novosibirsk, Nauka (in Russian).

Gömürgen, A. N. (2005). Cytological effect of the potassium metabisulphite and potassium nitrate food preservative on root tip of Allium cepa L. Cytologia, 70(2), 119-128.

Grant, W. F. (1982). Chromosome aberration assays in Allium. Mutation Research, Fundamental and Molecular Mechanisms of Mutagenesis, 99, 273-291.

Grant, W. F. (1994). The present status of higher plant bioassays for the detection of environmental mutagens. Mutation Research, Fundamental and Molecular Mechanisms of Mutagenesis, 310(2), 175-185.

Hosseinzadeh, Z., Ramazani, A., \& Razzaghi-Asl, N. (2019). Plants of the genus Heracleum as a source of coumarin and furanocoumarin. Journal of Chemical Reviews, 1(2), 78-98.

Jahodová, S., Trybush, S., Pysek P., Wade, M., \& Karp, A. (2007). Invasive species of Heracleum in Europe: An insight into genetic relationships and invasion history. Diversity and Distributions, 13(1), 99-114.

Jakubska-Busse, A., Sliwinski, M., \& Kobylka, M. (2013). Identification of bioactive components of essential oils in Heracleum sosnowskyi and Heracleum mantegazzianum (Apiaceae). Archives of Biological Sciences, 65(3), 877-883.

Karpova, S. S., Al'-Khachami, F. R. H., Kalaev, V. N., Ignatova, I. V., \& Slavskij, V.A. (2020). Tsitogeneticheskij polimorfizm semennogo potomstva derevjev orekha gretskogo (Juglans regia L.) pri introduktsii v Voronezhskoj oblasti. [Cytogenetic polymorphism of walnut trees (Juglans regia L.) seed progeny during introduction in the Voronezh region]. Ekologiya Urbanizirovannykh Territorij, 2, 21-29 (in Russian).

Kenne, K., Ljungquist, S., \& Ringertz, N. R. (1986). Effects of asbestos fibers on cell division, cell survival and formation of thioguanine resistant mutants in Chinese hamster ovary cells. Environmental Research, 39, 448-464.

Kurás, L. (2004). Characterization of protei-DNA association in vivo by chromatin immunoprecipitation. Methods of Molecular Biology, 284, 147-162.

Laman, N. A., \& Usik, A. V. (2020). Lokalizatsiya i sostav kumarinov v komyakh borshhevika sosnovskogo (Heracleum sosnowskyi Manden.) [Localization and composition of coumarins in roots of Heracleum sosnowskyi Manden.]. Izvestiya Natsional'noj Akademii Nauk Belarusi, Seriya Biologicheskikh Nauk, 65(1), 71-75 (in Russian). 
Leme, D. M., \& Marin-Morales, M. A. (2009). Allium cepa test in environmental monitoring: A review on its application. Mutation Research, Reviews in Mutation Research, 682(1), 71-81.

Li, D., Huang, Q., Lu, M., Zhang, L., Yang, Z., Zong, M., \& Tao, L. (2015). The organophosphate insecticide chlorpyrifos confers its genotoxic effects by inducing DNA damage and cell apoptosis. Chemosphere, 135, 387-393.

Madić, V., Jovanović, J., Stojilković, A., Jušković, M., \& Vasiljević, P. (2017) Evaluation of cytotoxicity of "anti-diabetic" herbal preparation and five medicinal plants: An Allium cepa assay. Biologica Nyssana, 8(2), 151-158.

Madike, L. N., Takaidza, S., Ssemakalu, C., \& Pillay, M. (2019). Genotoxicity of aqueous extracts of Tulbaghia violacea as determined through an Allium cepa assay. South African Journal of Science, 115, 1-6.

Maggi, F., Quassinti, L., Bramucci, M., Lupidi, G., Petrelli, D., Vitali, L. A., Papa, F., \& Vittori, S. (2014). Composition and biological activities of hogweed Heracleum sphondylium L. subsp. ternatum (Velen.) Brummitt essential oil and its main components octyl acetate and octyl butyrate. Natural Product Research, $28,1354-1363$

Mazzeo, D. E., Fernandes, T. C., \& Marin-Morales, M. A. (2011). Cellular damages in the Allium cepa test system, caused by BTEX mixture prior and after biodegradation process. Chemosphere, 85, 13-18.

Medvedeva, M. Y., Bolsunovsky, A. Y., \& Zotina, T. A. (2014). Cytogenetic abnormalities in aquatic plant Elodea canadensis in anthropogenic contamination zone of Yenisei River. Contemporary Problems of Ecology, 7(4), 422-432.

Mishyna, M., Laman, N., Prokhorov, V., \& Fujii, Y. (2015). Angelicin as the principal allelochemical in Heracleum sosnowskyi fruit. Natural Product Communications, 10(5), 767-770.

Moshafi, M. H., Sharififar, F., Dehghan, G. R., \& Ameri, A. (2009). Bioassay screening of the essential oil and various extracts of fruits of Heracleum persicum Desf. and rhizomes of Zingiber officinale Rosc. using brine shrimp cytotoxicity assay. Iranian Journal of Pharmaceutical Research, 8(1), 59-63.

Musikhin, P. V., \& Sigaev, A. A. (2006). Issledovanie fizicheskikh svojstv i khimicheskogo sostava borshhevika sosnovskogo i poluchenie iz nego voloknistogo polufabrikata [Investigation of physical properties and chemical composition of Heracleum sosnowskyi and production of fiber semi-product from it]. Sovremennye Naukoemkie Tekhnologii, 3, 65-67 (in Russian).

Musorina, T. A., Naumova, E. A., Shonina, E. V., Petrichenko, M. R., \& Kukolev, M. I. (2019). Teplotekhnicheskie svojstva ehnergoehffektivnogo materiala na osnove rastitel'noj dobavki (sukhoj borshhevik) [Heat engineering properties of energy-efficient material based on plant additives (dried hogweed)]. Vestnik MGSU, 14(12), 1555-1571 (in Russian).

Nabeel, M., Abderrahman, S., \& Papini, A. (2008). Cytogenetic effects of Arum maculatum extract on the bone marrow cells of mice. Caryologia, 61(4), 383-387.

O'Hare, S., \& Atterwill, C. K. (1995). In vitro toxicity testing protocols. Humana Press, Springer, Heidelberg.

Olorunfemi, D. I., Ogieseri, U. M., \& Akinboro, A. (2011). Genotoxicity screening of industrial effluents using onion bulbs (Allium cepa L.). Journal of Applied Sciences and Environmental Management, 15(1), 211-216.

O'Neill, T., Johnson, J. A., Webster, D., \& Gray, C. A. (2013). The Canadian medicinal plant Heracleum maximum contains antimycobacterial diynes and furanocoumarins. Journal of Ethnopharmacology, 147(1), 232-237.

Pesnya, D. S., Romanovsky, A. V., Serov, D. A., \& Poddubnaya, N. Y. (2017). Genotoxic effects of Heracleum sosnowskyi in the Allium cepa test. Caryologia, $70(1), 55-61$.

Prajitha,V., \& Thoppil, J. E. (2016). Genotoxic and antigenotoxic potential of the aqueous leaf extracts of Amaranthus spinosus Linn. using Allium cepa assay. South African Journal of Botany, 102, 18-25.
Ribeiro, I. A. (2018). Allium test in enviromental monitoring and healh. Novas Edições Acadêmicas. OmniScriptum Publishing KS, Mauritius.

Serrano-Garcia, L., \& Monteiro-Montoya, R. (2001). Micronuclei and chromatid buds are the result of related genotoxic events. Environmental and Molecular Mutagenesis, 38(1), 38-45.

Shakhmatov, E. G., Atukmaev, K. V., \& Makarova, E. N. (2016). Structural characteristics of pectic polysaccharides and arabinogalactan proteins from Heracleum sosnowskyi Manden. Carbohydrate Polymers, 136, 1358-1369.

Sharma, S., \& Vig, A. P. (2012). Genotoxicity of atrazine, avenoxan, diuron and quizalofop-P-ethyl herbicides using the Allium cepa root chromosomal aberration assay. Terrestrial Aquatic Environmental Toxicology, 6(2), 90-95.

Sharma, S., Panneerselvam, N., \& Ma, T. H. (1990). Genetic toxicology of pesticides in higher plant systems. Critical Reviews in Plant Sciences, 9(5), 409-442.

Souri, E., Farsam, H., Sarkheil, P., \& Ebadi, F. (2008). Antioxidant activity of some furanocoumarins isolated from Heracleum persicum. Pharmaceutical Biology, 42, 396-399.

Sudhakar, R., Ninge, G. K. N., \& Venu, G. (2011). Mitotic abnormalities induced by silk dyeing industry effluents in the cells of Allium cepa. Cytologia, 66(3), 235-239.

Sultan, A. O., \& Celik, T. A. (2007). Cytotoxic and genotoxic effects of Lavandula stoechas aqueous extracts. Biologia, 62(3), 292-296.

Sultan, A. O., \& Celik, T. A. (2010). Evaluation of cytotoxicity and genotoxicity of Inula viscosa leaf extracts with Allium test. Journal of Biomedicine and Biotechnology, 2010, 189252.

Tedesco, S. B., \& Laughinghouse IV, H. D. (2012). Bioindicator of genotoxicity: the Allium cepa test. In: Srivastava. J. (Ed.). Environmental Contamination. InTech, Croatia.

Timoshevskij, V. A., \& Nazarenko, S. A. (2006). Biologicheskaya indikatsiya mutagennykh vozdejstvij geneticheskoj nestabil'nosti u cheloveka putem ucheta chislovykh khromosomnykh narushenij [Biological indication of the mutagenic influences and genetic instability by aneuploidy detection]. Vestnik Genetiki i selekcii, 10(3), 530-539 (in Russian).

Tkachenko, K. G. (2015). Borshheviki (rod Heracleum (L.): Pro et contra [Giant hogweeds (genus Heracleum (L.): Pro et contra]. Biosfera, 7(2), 209-219 (in Russian).

Trott, J., Gerber, W., Hammes, S., \& Ockenfels, H. M. (2008). The effectiveness of PUVA treatment in severe psoriasis is significantly increased by additional UV 308-nm excimer laser sessions. European Journal of Dermatology, 18(1), 55-60.

Ventura-Camargo, B. C., Angelis, D. F. \& Marin-Morales, M. A. (2016). Assessment of the cytotoxic, genotoxic and mutagenic effects of the commercial black dye in Allium cepa cells before and after bacterial biodegradation treatment Chemosphere, 161, 325-332.

Visockiene, J. S., Tumeliene, E., \& Maliene, V. (2020). Identification of Heracleum sosnowskyi-invaded land using earth remote sensing data. Sustainability, 12(3), 759.

Walasek, M., Grzegorczyk, A., Malm, A., \& Skalicka-Wozniak, K. (2015). Bioactivity-guided isolation of antimicrobial coumarins from Heracleum mantegazzianum Sommier \& Levier (Apiaceae) fruits by high-performance countercurrent chromatography. Food Chemistry, 186, 133-138.

Wang, W., Gorsuch, J. W., \& Hughes, J. S. (1997). Plants for environmental studies. CRC Lewis Publisher, Boca Raton, New York.

Wierzbicka, M., \& Antosiewicz, D. (1988). Allium test-some questions. Acta Societatis Botanicorum Poloniae, 57(2), 201-215.

Yurlova, L. Y., Chernyak, D. M., \& Kutovaya, O. P. (2013). Furokumariny Heracleum sosnowskyi i Heracleum moellendorffi [Furocoumarins of Heracleum sosnowskyi and Heracleum moellendorffi]. Tikhookeanskij Meditsinskij Zhurnal, 52,91-93 (in Russian). 